\title{
Implementasi Manajemen Pemasaran Jasa Pendidikan Di MTs Ma’arif 1 Ponorogo
}

\author{
Ali Fahrudin', Murtadlo², Warih Handayaningrum ${ }^{3}$ \\ ${ }^{123}$ Prodi Manajemen pendidikan, Universitas Negeri Surabaya \\ Email: ali.19011@mhs.unesa.ac.id
}

\begin{abstract}
Marketing management of educational services will be good if it is carried out effectively and efficiently in a professional manner. This is done as an effort to make it easier for educational institutions to market their services to the public. The purpose of this study is to describe and analyze the implementation of marketing management of educational services at MTs Ma'arif 1 Ponorogo. This research uses descriptive qualitative method. The results of this study are, MTs Ma'arif 1 Ponorogo Implements the education marketing mix as follows: (1) product strategy, (2) price strategy, (3) place strategy, (4) promotion strategy, (5) people strategy, (6 ) physical eventdance strategy, (7) process strategy. In addition, there are various developments in marketing strategies carried out by MTs Ma'arif 1 Ponorogo in the face of competition between educational institutions.
\end{abstract}

Keywords: Management, Marketing, Educational Services.

Abstrak. Manajemen pemasaran jasa pendidikan akan baik apabila dilaksasnakan dengan efektif dan efisien secara profesional. Hal tersebut dilakukan sebagai upaya untuk mempermudah lembaga pendidik dalam memasarkan jasanya kepada masyarakat. Tujuan dari penelitian ini adalah mendeskripsikan dan menganalisis implementasi manajemen pemasaran jasa pendidikan di MTs Ma'arif 1 Ponorogo. Penelitian ini menggunakan metode kualitatif deskriptif. Hasil penelitian ini adalah, MTs Ma'arif 1 Ponorogo Mengimplementasikan bauran pemasaran pendidikan sebgai berikut: (1) strategi produk, (2) strategi price, (3) strategi place, (4) strategi promotion, (5) strategi people, (6) strategi physical evendance, (7) strategi process. Selain itu ada berbagai perkembangan strategi pemasaran yang dilakukan oleh MTs Ma'arif 1 Ponorogo dalam menghadapi kompetisi antar lembaga pendidikan.

Kata Kunci: Manajemen, Pemasaran, Jasa Pendidikan

\section{PENDAHULUAN}

Pada era industri 4.0 saat ini, lembaga pendidikan di hadapkan dengan berbagai tantangan dalam persaingan antar lembaga pendidikan. Masayarakat akan di hadapkan dengan banyaknya pilihan sekolah mana yang akan menjadi tujuan untuk menyekolahkan anaknya. Persaingan antar lembaga pendidikan tidak bisa di hindari, oleh sebab itu lembaga pendidikan membutuhkan tenaga profesional yang mampu mengelola lembaga dan melakukan pemasaran jasa pendidikan untuk memenuhi kebutuhan konsumen sebagai pengguna jasa pendidikan dan juga mempertahankan eksistensi sekolah.

Dewasa ini kompetisi antar sekolah terjadi sangat ketat antara sekolah berbasis agama (madrasah) dengan sekolah umum (SMA/SMK). Pembukaan beberapa jurusan - jurusan baru di sekolah umum menjadi tantangan bagi madrasah karena secara otomatis sekolah umum akan menambah jumlah kelas dan kuantitas input siswa akan bertambah. Sedangkan sekolah berbasis agama (madrasah) kurang peminat karena minimnya informasi tentang madrasah dan kurangnya penyesuaisan madrasah dengan kebutuhan pengguna jasa pendidikan saat ini. Berakibat pada presepsi masyarakat bahwa madrasah menjadi pilihan nomor dua setelah sekolah umum.

Transformasi teknologi dan informasi di era industri 4.0 menjadi salah satu tantangan bagi generasi setiap bangsa. Oleh karena itu setiap bangsa banyak yang bersaing untuk menigkatkan kualits sumber daya manusianya, melalui perbaikan kualitas pendidikan. Karena dengan pendidikan akan mampu meningkatkan kualitas manusia dan peradaban suatu bangsa yang 
berdaya saing (Sarifudin \& Maya, 2019). Lembaga pendidikan memiliki pekerjaan rumah untuk membenahi sistem pendidikan yang sedang berjalan yang harus disesuaikan dengan kebutuhan saat ini. Inovasi merupakan langkah kongrit yang perlu di lakukan oleh setiap sekolah untuk memberikan kepuasan bagi pengguna jasa pendidikan. Saat ini masyarakat sudah cerdas dalam menentukan pilihan sekolah bagi anaknya, mereka akan mengeluarkan biaya berapapun untuk sebuah kualitas pendidikan yang sesuai kebutuhannya (Abd, 2012). Apabila terdapat lembaga pendidikan tidak merespon positif kebutuhan masayarakat saat in maka secara perlahan akan tertinggal dan ditinggalkan oleh masyarakat.

Sebagai lembaga yang memiliki orientasi untuk memproduksi kualitas sumber daya manusia maka harus mampu memberikan presepsi yang positif dan membangun kepercayaan pada masyarakat sebgai pengguna jasa pendidikan. Sekolah harus berinisiatif untuk melakukan transformasi sitem pelayanannya, di awali dari melakukan proses analisis sasaran pasar atau segmentasinya, perencaan pemasaran, pengorganisasian yang sesuai dengan kemampuan SDM yang ada, pelaksaan yang terkendali dengan baik dan secara kontinyu melakukan proses evaluasi (Haryanto \& Rozza, 2012). Setiap lembaga pendidik harus mampu merencanakan rancangan sebuah lembaga yang dikelolanya dan menetapkan konsep strategi bauran pemasaran apa saja yang dapat membangun kepercayaan dan menciptakan kepuasan pengguna jasa pendidikan (Fajri \& Wiyani, 2019). Misalnya penawaran berbagai program ekstrakuliruler bagi siswa yang sesaui dengan penjabaran dari visi misi sekolah, serta secara konsistem memberikan informasi mengenai perkembangan lembaga secara transparan.

Konsep dari pemasaran pendidikan yaitu untuk memberikan pelayanan yang memuaskan bagi pelanggan atau pengguna jasa pendidikan, yaitu utamanya adalah peserta didik sebgai objek utama dari proses pembelajaran di sebuah lembaga pendidikan. Pemasaran dilakukan memiliki tujuan untuk (1) memberikan informasi kepada calon pengguna jasa pendidikan mengenai lembaga program sekolah, mempengaruhi dan meningkatkan daya tarik masyarakat, (3) membembedakan kualitas produk antara lembaga yang lain, (4) membentuk presepsi masayakat tentang sekolah yang bernilai baik, dan (5) menjaga eksistensi lembaga pendidikan (Faizin, 2017).

Lembaga pendidikan dalam memasarkan produk jasa pendidikannya perlu memiliki strategi yang tepat untuk memuaskan masyarakat sebgai pengguna jasa yang memiliki orientasi besar pada lembaga pendidikan. Oleh karena itu lembaga pendidikan harus mampu membuat citra lembaga pendidikan yang baik dimata masyarakat. Citra yan baik adalah kesan positif masyarakat yang merek aperoleh dari berbagai informasi tentang pengalaman dan pengetauan sesorang yang pernah menggunakan jasa pendidikan. Citra yang baik akan memiliki dampak positif terhadap sebuah organisasi profit maupun non profit, akan tetapi sebaliknya apabila citra baik tidak dimiliki maka organisasi akan mengalami kerugian (Margareta et al., 2018).

Dalam pemasaran pendidikan pelanggan membutuhukan perhatian kusus, karena mereka sebagai orang yang memiliki pengaruh terhadap proses pemasaran lembaga pendidikan. Terdapat dua jenis pelanggan pendidikan yaitu pelanggan internal dan eksternal. Pelanggan internal yaitu setiap orang yang terlibat dalam sistem lembaga pendidikan yaitu seluruh tenaga pendidik sekolah. Sedangkan pelanggan eksternal terbagi menjadi tiga yaitu primer (siswa/murid), sekunder ( wali murid, masyarakat dan pemerintah) dan tersier (mereka yang menjadi pengguna atau penerima produk pendidikan). Seluruhnya memiliki karakteristik masing masing dalam melakukan proses pemasaran pendidikan (Ilmiah et al., 2020).

Setiap lembaga pendidikan yang memiliki orientasi keberhasilan dalam memproduksi sumber daya yang berkualitas maka perlu berusaha dengan maskimal dalam mengimlementasikan total quality management, karena semua lembaga pasti akan berkompetisi untuk mempertahankan eksistensinya (Hidayat \& Machali, 2012). Seiring dengan permintaan konsumen, maka perlu adanya kebijakan pemasaran pendidikan yang memiliki keseimbangan nilai dan mutu sekolah. Kebijakan 
dibuat untuk menciptakan kepercayaan pengguna jasa pendidikan, misalnya dengan melakukan peningkatan kompetensi tenaga pendidik melalui training sesuai kebutuhan mereka. Kompetensi merupakan salah satu yang diperhatikan oleh pengguna jasa pendidikan untuk menilai suatu lembaga pendidikan yang dipilihnya (Faizin, 2017). Guru dan murid sebagai komponen yang utuama dalam lembaga pendidikan secara konsep idelaitas dan realitas harus memiliki karakter yang baik. Mereka memiliki karakternya masing - masing yang mana tidak hanya dilihat dari penilaian secara umum berupa nilai yang berlaku dalam raport (Wahyudi, 2017).

Pada saat ini sudah banyak lembaga pendidikan bertransformasi untuk melakukan peningkatan mutu dengan adanya kolaborasi kurikulum yang dibuat oleh pemerintah dengan kurukulum produk lokal lembaga pendidikan. Hal ini dilakukan sebgai upaya untuk proses perbaikan dan mewujudkan lembaga pendidikan yang bermutu. Terjadi dalam lembaga pendidikan islam yang saat ini sudah melakukan perpaduan kurikulum untuk menciptakan nilai dan kepercayaan masyarakat terhadap madrasah. Madrasah berada sebgai bukti kemajuan umat islam dalam dunia pendidikan, sejalan bahwa dengan pendidikan kemunduran umat islam akan teratasi untuk kemudian melakukan proses kemajuan dengan pengelolaan lembaga pendidikan yang profesional (Subaidi \& Nasukha, 2017).

Salah satu lembaga pendidikan islam (madrasah) yang saat ini memiliki citra yang baik di masyarakat yaitu MTs Ma'arif 1 Ponorogo. Madrasah yang berdiri sejak 2011 ini mampu melakukan pemasaran di tengah persaingan lembaga pendidikan yang semakin ketat, terbukti dengan masih eksisnya lembaga pendidikan ini meskipun secara lokasi berdekatan dengan sekolah - sekolah umum. Berdasarkan uraian tersebut maka penulis akan membahas penelitian tentang implementasi manajemen pemasaran jasa pendidikan dai MTs Ma'arif 1 Ponorgo. Dalam penelitian ini akan mendeskripsikan dan menganalisis proses implementasi pemasaran jasa pendidikan yang dilakukan oleh MTs Ma'arif 1 Ponorogo.

\section{METODE PENELITIAN}

Penelitian yang dilakukan di MTs Ma'arif 1 Ponorogo ini, peneliti menggunakan metode kualitatif deskriptif. Lembaga pendidikan ini dalam naungan Yayasan AlIttihad Ponorogo dan berafiliasi dengan Lembaga Pndidikan ma'arif Ponorogo. Sumber data primer diperoleh dari wawancara tenaga pendidik di MTs Ma'arif 1 Ponorogo, yaitu kepala madrasah, guru dan murid. Sedangkan data sekunder diperoleh dari kajian literatur (buku), dokumentasi dan berbagai dokumen yang memiliki keterkaitan dengan objek penelitian kususnya pemasaran pendidikan. Peneliti juga melakukan proses observasi dan dokumentasi lapangan dalam pengumpulan data secara langsung .

\section{HASIL DAN PEMBAHASAN}

Dari hasil penelitian yang dilakukan di MTs Ma'arif 1 Ponorogo ini peneliti menemukan manajemen pemasaran pendidikan yang dilakukan adalah menggunakan konsep strategi bauran pemasaran jasa pendidikan.

\section{Strategi Bauran Pemasaran jasa pendidikan} di MTs Ma’arif 1 Ponorogo

\section{Strategi Produk}

MTs Ma'arif 1 Ponorogo memiliki komitmen yang kuat untuk memberikan pelayanan pendidikan yang ungul, hal ini sesuai dengan yang tertuang dalam visi madrasah "unggul dalam penguasaan IPTEK berakhlakul karimah dan berbudaya". Semenjak berdirinya di tahun 2011 MTs Ma'arif 1 Ponorogo telah memiliki pasar tersendiri, meskipun keberadaannya termasuk pendatang baru. Melalui konsep madrasah berbasis riset, madrasah memiliki beberapa program kurrikuler untuk mendukung potensi setiap murid. Madrasah ini berada di dalam lingkungan pesantren yang mana mimiliki kekhasan dalam bentuk budaya dan akhlaknya, hal ini menjadi kekuatan tersendiri seiring dengan antusias masyarakat yang semakin tinggi mempercayakan pendidikan anaknya kepada pesantren.

Semenjak berdirinya tahun 2011, MTs Ma'arif 1 Ponorogo telah mampu membuktikan kualitas pendidikannya melalui berbagai prestasi akademik dan non akademik 
yang diraih oleh muridnya. Dengan karakteristik budaya kepesantrenannya kuat, MTs Ma'arif 1 Ponorogo mudah diterima di masyarakat, hal ini juga di pengaruhi oleh program pengabdian yang dilakukan oleh madrasah kepada masyarakat untuk melatih murid memiliki kepedulian sosial yang tinggi setelah nanti dia lulus dari madrasah.

2. Strategi Price

Pembiayaan pendidikan di MTs Ma' 'arif 1 Ponorogo ini memiliki cara tersendiri dalam menentukan berapa harga yang harus dibayarkan oleh orang tua murid untuk biaya pendidikan anaknya. Besaran biaya pendidikan perbulan sebesar 380.000 ,- sudah termasuk asarama dan makan tiga kali sehari. Akan tetapi melihat kemampuan masyarakat yang berbeda - beda, madrasah memberikan pilihan kemampuan setiap wali murid berapa yang bisa di bayarkan untuk pendidikan anaknya. Selain itu program santri asuh juga diberikan bagi murid yang berasal dari keluarga tidak mampu atau yatim yang nantinya akan diikut sertakan dalam program LKSA (lembaga kesejahteraan sosial dan anak) Ittihadul Inayah Ponorogo. Bagi murid yang berprestasi akan diberikan beasiswa prestasi oleh madrasah.

3. Strategi Place

Keberadaan MTs Ma'arif 1 Ponorogo terletak di tengah pusat kabupaten ponorogo, berdampingan dengan beberapa sekolah dan madrasah besar di sekitarnya. Akses masuk ke madrasah sangat mudah karena berada di dekat jalan raya utama kabupaten. Luas lahan madrasah \pm 5 hektar dan karena sebagai lembaga pendidikan yang baru, sampai saat ini masih dalam proses pengembangan sarana prasarana pendidikan. Madrasah ni berada dalam lingkungan pondok pesantren Ittihadul Ummah Ponorogo.

\section{Strategi Promotion}

Promosi yang dilakukan oleh MTs M'arif 1 Ponorogo melalui beberapa cara yang digunakan. Karena merupakan lembaga pendidikan yang berafiliasi dengan jam 'iyyah diniyah Nahdlatul Ulama' (NU) maka mdarasah menggunakan jejaring organisasi dalam melakukan pemasaran madrasah. Program kemasayarakan menjadi salah satu strategi yang dilakukan madrasah dengan konsep pengabdian kemasyarakatan. Optimalisasi peranan alumni juga dilakukan dengan tersebarnya alumni pesantren di berbagai daerah.

Perkembangan teknologi dan informasi direspon dengan baik oleh madrasah, dengan adanya proses pemasaran dengan medis sosial. Setiap aktifitas mdarasah dan prestasi murid terus di publikasikan melalui media sosial lembaga dengan tujuan untuk memberikan informasi kepada masyarakat mengenai perkembangan madrasah. Facebook, instagram dan website madrasah menjadi salah satu kekuatan tersendiri dengan derasnya arus informasi melalui media digital.

\section{Strategi People}

Kegiatan pembelajaran menjadi fokus utama sebuah lembaga pendidikan berdiri. MTs Ma'arif 1 Ponorogo dalam hal penyediaan tenaga pendidik sangat memperhatikan kualitas secara intelektual dan moral. Kualifikasi pengajar sesuai dengan bidang yang di ampu oleh setiap pendidik, terdiri dari starata satu (S1) dan Magister (S2). Setiap dari pendidik diberikan kesempatan untuki mengembangkan kompetensinya melalui berbagai program yang ingin ditempuhnuya. Dari pihak yayasan yang menaungi madrasah memberikan pelatihan secara berkala dan mengevaluasi perkembangan secara akademik pendidik dan paling utama adalah akhlaq pendidik.

6. Strategi Physical Evidance

Fasilitas yang di miliki oleh madrasah sudah mencukupi untuk men dukung terselenggaranya aktifitas belajar mengajar. Kelas yang representatif dan laboratorium untuk pengembangan potensi diri murid dan mendalami mata pelajaran yang ditempuhnya. Sarana untuk aktifitas fisik berupa lapangan olah raga juga tersedia. MTs Ma'arif 1 Ponorogo sedang melakukan pengembagan sarana prasarana mulai dari kelas, lapangan, kamar mandi, ruang kantor dan aula. Sebagai pendatang baru madrasah ini sudah memiliki fasilitas yang cukup memadai untuk mendukung terselengaranya proses belajar mengajar yang efektif dan efisien.

7. Strategi Process 
MTs Ma'arif 1 Ponorogo dari aspek kurikulumnya menggunakan standar kurikulum nasional dan dikolaborasikan dengan kurikulum pesantren. Selain dari itu sebgai madrasah dengan tujuan untuk menjadi madrasah unggulan, MTs Ma'arif 1 Ponorogo memiliki kuikulum pembelajaran berbasis riset. Dimana kurikulum pembelajran berbasis riset ini menjadi khas bagi madrasah untuk mencetak produk pendidikan (alumni/murid) yang memiliki nalar kritis dan jiwa transformatif. Madrasah juga membuaka kritik dan saran dari wali murid dan masyarakat yang nantinya akan menjadi bahan evaluasi dalam pengembangan lembaga pendidikan kedepan.

\section{KESIMPULAN}

Dari penelitian yang telah dilakukan, peneliti memberikan kesimpulan bahwa MTs Ma'arif 1 Ponorogo dalam proses pemasaran pendidikan mengimplementasikan strategi bauran pemasaran. Yaitu sebagai berikut: pertama strategi produk yang dilakukan oleh MTs Ma'arif 1 Ponorogo adalah dengan memberikan berbagai program pembelajaran berupa pembelajaran berbasis riset dan program kurrikuler untuk pengembangan potensi murid. Kedua strategi price, biaya yang ditawar terjangkau dengan besaran 380.000,- dan bisa memilih sesuai dengan kemampuan wali murid. Ketiga strategi place, letak madrasah berada dalam lingkungan pesantren Ittihadul Ummah Ponorogo dan secara akses ke madrasah sangat mudah karena berada di dekat pusat kabupaten Ponorogo.

Keempat, strategi promosi yang dilakukan oleh MTs Ma'arif 1 Ponorogo menggunakan jejaring afiliasi organisasi yaitu basis Nahdlatul Ulama (NU), program kemasyarakatan dan media sosial sebagai salah satu media untuk menginformasikan perkembangan madrasah. Kelima, strategi people, ketersediaan tenaga pendidik sesuai dengan kualifikasi dan kompetensi untuk memberikan pelayanan pendidikan yang profesional. Tenaga pendidik yang dimiliki lembaga saat ini ada Sarjana (S1) dan Magister (S2). Keenam, strategi physical evidance, fasilitas yang dimiliki oleh MTs Ma'arif 1
Ponorogo memadahi untuk terselenggaranya proses kegiatan belajar mengajar yang efektif dan efisien. Ketujuh, strategi process, madrasah menggunakan perpaduan antara kurikulum nasional dan pesantren sebagai ciri khas madrasah, juga menggunakan kurikulum pembelajaran berbasis riset dengan tujuan untuk mencetak produk pendidikan yang kritis dan transformatif.

\section{SARAN}

Lembaga pendidik merupakan investasi sumber daya manusia dalam jangka panjang. Oleh karena itu proses pendidikan menjadi perhatian kusus yang harus ditangani oleh orang - orang profesional. Salah satu yang harus diperhatikan adalah pemasaran jasa pendidikan, hal ini sangat berpengaruh pada perkembangan lembaga pendidikan utamanya sekolah berbasis agama (madrasah). Sebagai pendatang baru MTs Ma'arif 1 Ponorogo untuk menghadapi kompetisi antar lembaga pendidikan, maka madrasah perlu menguatkan strategi dalam pemasaran jasa pendidikan. Input menjadi berpengaruh terhadap proses pendidikan dan keluaran atau produk yang nantinya akan dinikmati oleh masyarakat. Oleh sebab itu menjaga standart dan kualitas pendidikan harus dilakukan dengan baik untuk memberikan kepuasan terhadap masyarakat sebagai penguna jasa pendidikan.

\section{DAFTAR PUSTAKA}

\section{Sumber dari Jurnal}

Abd, H. (2012). Model pemasaran jasa pendidikan. 181-186.

Faizin, I. (2017). STIT Pemalang 261. Strategi Pemasaran Jasa Pendidikan Dalam Meningkatkan Nilai Jual Madrasah, 7, 261283.

https://journal.stitpemalang.ac.id/index.php /madaniyah/article/view/75

Fajri, N. S., \& Wiyani, N. A. (2019). Manajemen Marketing Sekolah Berbasis Information and Communication Technology. J-MPI (Jurnal Manajemen Pendidikan Islam), $4(2)$, https://doi.org/10.18860/jmpi.v4i2.7857

Haryanto, R., \& Rozza, S. (2012). Pengembangan Strategi Pemasaran Dan Manajemen Hubungan Masyarakat Dalam 
Meningkatkan Peminat Layanan Pendidikan. Juni, 11(2012), 2734.

Hidayat, A., \& Machali, I. (2012). Pengelolaan Pendidikan (Konsep, Prinsip, dan Aplikasi dalam Mengelola sekolah dan Madrasah). Universitas Pendidikan Indonesia, 4-6.

Ilmiah, J., Peningkatan, U., \& Penddikan, M. (2020). Sunarni, Maulana, Ayu, Mokhamad, Rusma, Septiani,Strategi Pemasaran sekolah .... Improvement, 7(2), 89-100.

Margareta, R. T. E., Ismanto, B., \& Sulasmono, B. S. (2018). Strategi Pemasaran Sekolah Dalam Peningkatan Minat Peserta Didik Berdasarkan Delta Model. Kelola: Jurnal Manajemen Pendidikan, 5(1), 1-14. https://doi.org/10.24246/j.jk.2018.v5.i1.p114

Sarifudin, S., \& Maya, R. (2019). Implementasi Manajemen Pemasaran Jasa Pendidikan Dalam Meningkatkan Kepuasan Pelanggan Di Madrasah Aliyah Terpadu (Mat) Darul Fallah Bogor. Islamic Management: Jurnal Manajemen Pendidikan Islam, 2(02), 133. https://doi.org/10.30868/im.v2i02.513

Subaidi, \& Nasukha, M. (2017). Strategi Pemasaran Lembaga Pendidikan Tinggi: Pendekatan Konsep Islamic Marketing. Wahana Akademika, 4(2), 204-217.

Wahyudi, K. (2017). Manajemen Pemasaran Pendidikan. Kariman, 05(01), 65-82.

\section{Sumber dari Buku}

Alma, B (2012). Manajemen Pemasaran dan Pemesaran Jasa. Bandung: Alfabeta.

Asmani, J.M (2015). Manajemen Efektif Marketing Sekolah Pertama. Yogyakarta: Diva Press

Haryati, Y. dan Muhsin, M (2014). Manajemen Sumber Daya Pendidikan, Bandung: CV Pustaka Setia.

Qomar, M. (2007). Manajemen Pendidikan Islam: Strategi Baru Pengelolaan lembaga Pendidikan, Yogyakarta: Ar-Ruzz Media 